\title{
Corrigendum: Chinese Trader Perceptions on Sourcing and Consumption of Endangered Seafood
}

\author{
Michael Fabinyi ${ }^{1,2,3 *}$, Kate Barclay ${ }^{1}$ and Hampus Eriksson ${ }^{3,4}$ \\ ${ }^{1}$ Faculty of Arts and Social Sciences, University of Technology Sydney, Sydney, NSW, Australia, ${ }^{2}$ Australian Research \\ Council Centre of Excellence for Coral Reef Studies, James Cook University, Townsville, QLD, Australia, ${ }^{3}$ WorldFish, Penang, \\ Malaysia, ${ }^{4}$ Australian National Centre for Ocean Resources and Security, University of Wollongong, Wollongong, NSW, \\ Australia
}

Keywords: sea cucumber, China, seafood trade, sustainability, food safety, environmental governance, sustainable seafood movement

\section{A Corrigendum on}

Chinese Trader Perceptions on Sourcing and Consumption of Endangered Seafood by Fabinyi, M., Barclay, K., and Eriksson, H. (2017). Front. Mar. Sci. 4:181. doi: $10.3389 /$ fmars.2017.00181

\section{OPEN ACCESS}

Edited and reviewed by: Annette Breckwoldt, Leibniz Centre for Tropical Marine

Research (LG), Germany

*Correspondence: Michael Fabiny michael.fabinyi@uts.edu.au

Specialty section

This article was submitted to Marine Conservation and Sustainability, a section of the journal Frontiers in Marine Science

Received: 17 January 2019 Accepted: 08 March 2019 Published: 02 April 2019

Citation:

Fabinyi M, Barclay $\mathrm{K}$ and Eriksson $\mathrm{H}$ (2019) Corrigendum: Chinese Trader Perceptions on Sourcing and Consumption of Endangered Seafood. Front. Mar. Sci. 6:152. doi: 10.3389/fmars.2019.00152
In the original article, there was a mistake in Table $\mathbf{3}$ as published. Incorrect conversion rates were used to convert prices from Chinese yuan per jin (500 gm) and from Hong Kong Dollars per Hong Kong catty (605 gm) to US Dollars per kilogram. The corrected Table 3 appears below.

As per the error reported above, a correction has been made to the Results, General Consumption Preferences, paragraphs one and three:

"Two major types of sea cucumbers are distinguished by Chinese traders, and consumption preferences differ depending on geographical location (Figure 1). Japanese spiky sea cucumbers, Apostichopus japonicus, are found in temperate waters in parts of China (especially Liaoning and Shandong provinces) and neighboring countries such as Korea, Russia, and Japan. While they are often captured in the wild, they are also cultured in large quantities (Chen, 2003; Han et al., 2016a). Commonly referred to as cishen, (spiky sea cucumber), the most highly valued individuals of these sea cucumbers reach the highest prices on the markets and are regarded as the best of all sea cucumbers (prices of USD316-1,892/kg). This is for several reasons: their spiky appearance is viewed as appealing (the longer the spikes, the better); they are of a suitable size to be served individually, whole; and they are regarded as having better nutrition and health benefits than other types of sea cucumbers. In much of northern China, these temperate sea cucumbers dominate the market."

"The prices of sea cucumbers vary significantly-from less than USD64/kg for dried, cheaper species of lower quality, to more than USD1,800/kg for high-value species of excellent quality (Table 3). A. japonicus was the most expensive type of sea cucumber in all locations, followed by sandfish (Holothuria scabra; H. lessoni) (price of USD64-359/kg) and teatfish (H. fuscogilva, H. nobilis, H. whitmaei) (price of USD96-319/kg). Other types of tropical sea cucumbers commonly sold include prickly redfish (Thelenota ananas), South American sea cucumbers (Isostichopus fuscus, I. badionotus), and curryfish (A. herrmanni) (prices of USD96-294/kg). Purcell (2014) has conducted a more comprehensive survey of tropical sea cucumber prices in southern China." 
TABLE 3 | Prices of selected sea cucumbers in USD/kg, September 2015.

\begin{tabular}{|c|c|c|c|c|c|c|c|}
\hline $\begin{array}{l}\text { Common } \\
\text { english } \\
\text { name }\end{array}$ & $\begin{array}{l}\text { Scientific } \\
\text { name }\end{array}$ & $\begin{array}{l}\text { Hong Kong } \\
\text { wholesale } \\
\text { price }\end{array}$ & $\begin{array}{l}\text { Hong Kong } \\
\text { retail price }\end{array}$ & $\begin{array}{l}\text { Guangzhou } \\
\text { wholesale } \\
\text { price }\end{array}$ & $\begin{array}{l}\text { Beijing } \\
\text { wholesale } \\
\text { price }\end{array}$ & $\begin{array}{l}\text { Shanghai } \\
\text { wholesale } \\
\text { price }\end{array}$ & Conservation status \\
\hline $\begin{array}{l}\text { Sandfish, } \\
\text { golden } \\
\text { sandfish }\end{array}$ & $\begin{array}{l}\text { Holothuria } \\
\text { scabra, H. } \\
\text { lessoni. }\end{array}$ & 196-338 & 84-359 & 64-156 & $128-220$ & $96-252$ & Endangered \\
\hline $\begin{array}{l}\text { White teatfish, } \\
\text { black teatfish }\end{array}$ & $\begin{array}{l}\text { H. fuscogilva, } \\
\text { H. nobilis, } H \text {. } \\
\text { whitmaei }\end{array}$ & $191-319$ & 166-294 & $96-156$ & $128-156$ & $96-152$ & $\begin{array}{l}\text { Endangered/Vulnerable } \\
\text { (H. fuscogilva) }\end{array}$ \\
\hline
\end{tabular}

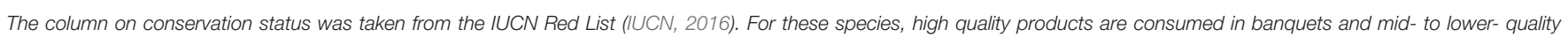
products are consumed at home and for family occasions.

Additionally, a correction has been made to the Results, Banqueting, paragraph two:

"Recently, however, the luxury sea cucumber market has witnessed a downturn. First, the government's anti-corruption campaign (Jeffreys, 2016) is viewed by traders to have had a significant effect on the sales of dried seafood generally. Hong Kong traders of dried seafood widely reported reduced profits over the past 2-3 years. One Hong Kong trader advised that the price of most kinds of BDM had dropped by $30-50 \%$ in the past year or so; others did not give specific figures or estimates but noted that demand had dropped, especially from mainland China. Guangzhou-based traders similarly noted how Japanese spiky sea cucumber had dropped from USD1,892/kg to USD $1,260 / \mathrm{kg}$ in the course of 2015 . Beijing traders reported significant declines in sales over the past years (see also Fabinyi and Liu, 2016). One Beijing trader spoke of an $80 \%$ drop in sales; another described a $70-80 \%$ drop in sales. Several dried seafood

\section{REFERENCES}

Chen, J. (2003). Overview of sea cucumber farming and sea ranching practices in China. SPC Beche-de-mer Inform. Bull. $18,18-23$.

Fabinyi, M., and Liu, N. (2016). The social context of the Chinese food system: an ethnographic study of the Beijing seafood market. Sustainability 8:244. doi: 10.3390/su8030244

Han, Q., Keesing, J. K., and Liu, D. (2016a). A review of sea cucumber aquaculture, ranching, and stock enhancement in China. Rev. Fish. Sci. Aquacult. 24, 326-341. doi: 10.1080/23308249.2016.11 93472

IUCN (2016). The IUCN Red List of Threatened Species. Available online at: http:// www.iucnredlist.org/ traders had closed since 2013. The anti-corruption campaign began shortly after Xi Jinping's ascent to the leadership in late 2012, and has continued and even intensified since then. One of the specific targets of this campaign was government officials using public funds at banquets. While sea cucumbers are not exclusively eaten at such banquets, a considerable proportion of them are. Secondly, another factor relating to demand has been the slowdown in the Chinese economy. Due to government policies aiming to transition to a slower but more sustainable economic growth pattern, since 2011 the growth rate of the Chinese economy has been slowing. However, the market for many of the mid- and low value sea cucumbers will likely continue to expand, especially in new markets throughout China, largely due to their popularity as a health product."

The authors apologize for this error and state that this does not change the scientific conclusions of the article in any way. The original article has been updated.
Jeffreys, E. (2016). Translocal celebrity activism: shark-protection campaigns in mainland China. Environ. Commun. 10, 763-776. doi: $10.1080 / 17524032.2016 .1198822$

Purcell, S. (2014). Value, market preferences and trade of bechede-mer from Pacific Island sea cucumbers. PLoS ONE 9:e95075. doi: 10.1371/journal.pone.0095075

Copyright (C) 2019 Fabinyi, Barclay and Eriksson. This is an open-access article distributed under the terms of the Creative Commons Attribution License (CC BY). The use, distribution or reproduction in other forums is permitted, provided the original author(s) and the copyright owner(s) are credited and that the original publication in this journal is cited, in accordance with accepted academic practice. No use, distribution or reproduction is permitted which does not comply with these terms. 